\title{
The effects of intravenous, glucose versus saline on ovarian follicles and their levels of some mediators of insulin signalling
}

\author{
Rex John Scaramuzzi ${ }^{1,2^{*}}$, Nesrine Zouaïdi ${ }^{1}$, Jean-Baptiste Menassol ${ }^{1,3}$ and Joëlle Dupont ${ }^{1}$
}

\begin{abstract}
Background: A short-term increase in food intake and specifically dietary energy can stimulate folliculogenesis and increase ovulation rate in ewes. The mechanism appears to involve the insulin-glucose metabolic system and its interaction with FSH signalling pathways in the granulosa cells of ovarian follicles. This experiment was designed to investigate the interaction between these two systems in the granulosa cells of ovarian follicles.

Methods: Thirty six lle-de-France ewes were used in this controlled experiment to study the effects of intravenous glucose on folliculogenesis. Eighteen ewes were infused with glucose $(10 \mathrm{mM} / \mathrm{h}$ for $72 \mathrm{~h})$ from day 8 of the oestrous cycle, while the others (controls) received saline. Ovaries were collected when the infusions ended (luteal phase) or $30 \mathrm{~h}$ later and after a luteolytic dose of a PGF $2 a$ analogue (follicular phase). Follicles were dissected and granulosa cells and follicular fluid harvested. The blood concentrations of glucose, insulin, oestradiol and FSH were monitored over the experiment. The levels of Aromatase $\mathrm{P}_{450}$ and of the phosphorylated and non-phosphorylated forms of Akt, AMPK and ERK in granulosa cells and the concentration of oestradiol in follicular fluid, were determined.

Results: Glucose increased the circulating concentration of glucose $(P<0.05)$ and insulin $(P<0.05)$. It also increased the total number of follicles $>1.0 \mathrm{~mm}$ in diameter $(P<0.05)$ and small $(P<0.05)$ follicles $(>1.0$ to $2.0 \mathrm{~mm}$ in diameter) but not medium (>2.0 to $3.5 \mathrm{~mm}$ in diameter) or large ( $>3.5 \mathrm{~mm}$ in diameter) follicles. Glucose decreased circulating oestradiol $(P<0.05)$ but not that of FSH or progesterone. Glucose reduced aromatase $P_{450}(P<0.05)$ and decreased the phosphorylation of Akt $(P<0.05)$, ERK $(P<0.05)$ and AMPK $(P<0.05)$ in granulosa cells from oestrogenic follicles. The level of Aromatase $P_{450}$ was greatest in large oestrogenic follicles and the phosphorylation of Akt $(P<0.05)$, ERK $(P<0.05)$ and AMPK $(P<0.05)$ was lower in small follicles compared to medium and large follicles.
\end{abstract}

Conclusions: These data suggest that the effect of glucose in small follicles is a direct action of glucose that increases the number of small follicles while the effect of glucose in oestrogenic follicles is an indirect insulin-mediated action.

Keywords: Sheep, Ewe, Nutrition, FSH, Oestradiol, Aromatase, AMPK, Akt, ERK

\section{Background}

Reproduction is subject to the influence of several factors related to the animal itself and to its environment. Among these, nutrition is one of the main factors affecting most aspects of the reproductive performance of the animal $[1,2]$. Lindsay and his colleagues $[1,2]$ recognized that an

\footnotetext{
* Correspondence: rex.scaramuzzi@orange.fr

'L'Institut National de la Recherche Agronomique, Unité Mixte de Recherche 6175, Physiologie de la Reproduction et des Comportements, Nouzilly 37380, France

${ }^{2}$ Department of Comparative Biomedical Sciences, The Royal Veterinary College, Hawkshead Lane, North Mimms, Hertfordshire AL9 7TA, UK Full list of author information is available at the end of the article
}

increase in short-term food intake increased the lambing rate in ewes by stimulating ovulation rate. Three effects of nutrition on ovulation rate, the "acute", "dynamic" and "static" effects, have been described [2,3] although there is uncertainty over the number of mechanisms involved [3]. The acute effect is an effect of diet associated with weight change, the static effect is associated with the absolute level of body weight while the dynamic effect is a shortterm dietary effect not accompanied by a change in weight [reviewed in: 2, 3].

There have been numerous investigations of the relationship between diet and ovulation rate in farm animals 
and particularly sheep [2-4] and of the physiological mechanism(s) responsible for this phenomenon $[3,5,6]$. The inclusion of energy-dense foods such as lupin grain [7-13] or corn with soy meal [14] in the diet will increase both ovulation rate and the number of follicles. Other forms of nutritional manipulation for example, the infusion of leptin [15] or glucose [16-18] have been investigated and shown to increase both the ovulation rate and the number of follicles. So clearly, there is a link between nutrition and folliculogenesis. This relationship could involve effects mediated by the intrafollicular glucose-insulin system [3,5,6] and other energy sensing mechanisms such as the AMPK system $[6,19]$. Although there is an extensive literature (see references cited above) describing the effects of dietary energy on folliculogenesis and ovulation rate there are relatively few studies of the intrafollicular mechanisms that are affected by the energy content of the diet. The level of Aromatase $\mathrm{P}_{450}$ was reduced in follicles of ewes whose diet was supplemented with lupin grain [20] or infused with glucose [18] and in the former study these effects were associated with alterations in the level of expression of the insulin receptor substrate (IRSs) proteins and in the later study, they were associated with alterations in the levels of Akt and AMPK; and Akt is a phosphorylation target in the insulin signalling pathway. In addition the presence of the insulin dependent glucose transporter (GLUT4 or the sugar transport facilitator [SLC2A-4]) has been confirmed in ovine [21], bovine [22] and rodent [23] ovarian follicles. Finally, insulin has been identified as a factor in several malfunctions of the ovary and its follicles in a number of ovarian pathologies [24]. These data suggest that insulin signalling to granulosa cells is implicated in the effects of dietary energy on folliculogenesis.

To improve the understanding of the interaction between folliculogenesis and the metabolic status of ewes we studied the effect of intravenous glucose on the insulin-signaling pathways in granulosa cells of follicles collected from ewes in either the luteal or follicular phases of the oestrous cycle. Although several potential metabolic sensors have been identified, including the IGF system, GH, and leptin $[25,26]$ we have focused our attention on the insulin-glucose and AMPK systems. A preliminary report of certain aspects of this study has been published [27].

\section{Methods}

\section{Animals}

The experiment was conducted at the INRA laboratory at Nouzilly in France between August and September using 36 Ile-de-France ewes. During the experiment the ewes were housed in group pens until they were fitted bilaterally with catheters in their jugular veins. Following catherization the ewes were placed in individual pens and kept there until the end of the infusion period. Then they were either ovariectomised immediately (the 2 luteal phase groups) or returned to group pens where they were left until ovariectomy $30 \mathrm{~h}$ after the end of infusion (the 2 follicular phase groups). During the experiment the ewes were fed a basal diet of good quality hay at maintenance levels [28] with ad libitum access to straw roughage and fresh water. The experiment was carried with local ethical approval and in accordance with French and European regulations on the care and welfare of animals in research and with ethical approval from the Ministry of Agriculture ( ${ }^{\circ} 006259$ and 2012-01-2).

The experimental plan is shown in Figure 1, briefly, oestrus was synchronised using progestagen sponges (Chronogest; Intervet/Schering-Plough Animal Health, Angers, France). Eight days after oestrus one group ( $\mathrm{n}=18$ ) was infused with glucose at $10 \mathrm{mM} / \mathrm{h}$ for $72 \mathrm{~h}$. A second group was infused with physiological saline at the same rate $(n=18)$ and acted as controls. At the end of the infusion ovaries were collected from half the ewes

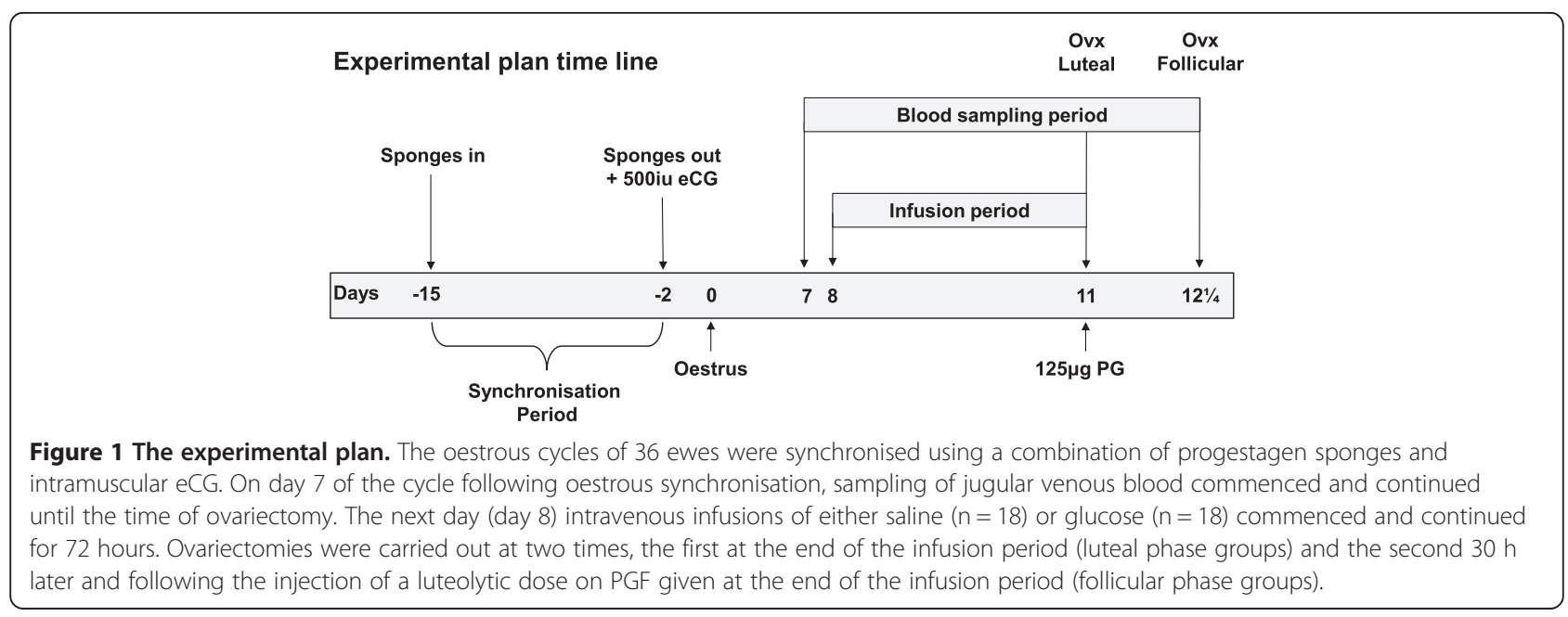


in each treatment group to form the two luteal phase groups. Luteolysis was induced with $125 \mu \mathrm{g}$ of an analogue of $\mathrm{PGF}_{2 \alpha}$ (Cloprostenol; Intervet/Schering-Plough Animal Health, Angers, France) in the remaining ewes whose ovaries were collected $30 \mathrm{~h}$ after the end of infusion to form the two follicular phase groups. The body weights of the ewes were measured at the start of the infusion and at the time of ovariectomy.

\section{Blood collection}

Two days before the start of the infusions both jugular veins were fitted with intravenous catheters. One catheter was used exclusively for infusions and the other exclusively for sampling blood. A sterile, 18\% (w/v) solution of glucose was used and the rate of infusion was adjusted to deliver glucose at a rate of $10 \mathrm{mM}$ per hour. The controls were infused with sterile saline at the same rate. The infusions were started on day 8 of the oestrous cycle and were continued for $72 \mathrm{~h}$ until day 11. Samples $(5 \mathrm{~mL})$ of jugular venous blood were collected regularly throughout the experiment as follow: For the determination of the plasma concentrations of oestradiol-17 $\beta$, progesterone and FSH samples were taken every $6 \mathrm{~h}$ from $-24 \mathrm{~h}$ relative to the start of infusion until ovariectomy. These samples were collected into lithium heparin tubes. For glucose and insulin samples were taken 24 hours before the start of the infusions and then at $0,3,9,24,48$ and 72 hours after the start of the infusion. These samples were collected into fluoride/EDTA tubes. The blood samples were centrifuged at $4^{\circ} \mathrm{C}$ for 20 minutes at 1,000 g. The plasma was then decanted and stored at $-20^{\circ} \mathrm{C}$.

\section{Collection and dissection of ovaries}

The animals were ovariectomised under pentothal-induced, halothane-maintained anaesthesia, by the laboratory veterinarian. Within a minute of removal, the ovaries were placed in ice-cold sterile saline for transport from the surgery to the laboratory. In the laboratory, the number of corpora lutea was noted, the ovaries were weighed and all follicles $>1 \mathrm{~mm}$ in diameter were dissected out using fine scissors and fine toothed dissecting forceps. The isolated follicles were placed in ice-cold phosphate buffered saline (0.72 M Na $2 \mathrm{HPO}_{4} .2 \mathrm{H}_{2} 0 ; 0.28 \mathrm{M} \mathrm{Na}_{2} \mathrm{H}_{2} \mathrm{PO}_{4} .2 \mathrm{H}_{2} \mathrm{O}$ and $0.155 \mathrm{M} \mathrm{NaCl}$ at $\mathrm{pH}$ 7.0) in sterile, plastic Petri dishes and their average diameter measured to the nearest $\mathrm{mm}$ (for details, see below). From this point the follicles were processed individually as described [29]. Individual follicles were placed in a sterile plastic mini-Petri dish containing $1 \mathrm{ml}$ of sterile phosphate buffered saline. Each follicle was then hemisected and the granulosa cell layer was gently scraped into the phosphate buffered saline using a fine plastic loop. The follicular shell of mainly theca cells was placed in a $1.5 \mathrm{~mL}$ micro-tube, snap frozen and stored at $-80^{\circ} \mathrm{C}$. The phosphate buffered saline containing, granulosa cells and follicular fluid was then placed into another $1.5 \mathrm{~mL}$ micro-tube and centrifuged at $4^{\circ} \mathrm{C}$ and $1,000 \mathrm{X} g$ for $10 \mathrm{~min}$. Following centrifugation, the supernatant containing diluted follicular fluid was transferred into a $1.5 \mathrm{~mL}$ micro-tube snap frozen and stored at $-20^{\circ} \mathrm{C}$. The separated granulosa cell pellet was also snap-frozen and stored at $-80^{\circ} \mathrm{C}$.

\section{Measurement and classification of follicles}

The diameter of all dissected follicles was measured in two dimensions at $90^{\circ}$, using a graph paper grid placed below the Petri dishes that contained the dissected follicles and the average diameter calculated. The follicles were then grouped into three classes based on their diameters. These were: small $>1.0-2.00 \mathrm{~mm}$; medium $>2.0$ to $3.5 \mathrm{~mm}$ and large $>3.5 \mathrm{~mm}$. Follicles were also classified on the basis of their oestrogenicity. Oestrogenic follicles were defined as those with a concentration of oestradiol in follicular fluid $>100 \mathrm{ng} / \mathrm{mL}$, and nonoestrogenic follicles as those with $<100 \mathrm{ng} / \mathrm{mL}$. These definitions allow us to identify the following categories of follicles:

(i) Large (diameter $>3.5 \mathrm{~mm}$ ) oestrogenic follicles

(ii) Large non-oestrogenic follicles

(iii) Medium (diameter $>2.0$ to $3.5 \mathrm{~mm}$ ) oestrogenic follicles

(iv) Medium non-oestrogenic follicles

(v) Small (diameter $>1.0$ to $2.0 \mathrm{~mm}$ ) oestrogenic follicles.

(vi) Small non-oestrogenic follicles.

The volume of follicular fluid volume was calculated as described previously [30].

\section{Glucose and hormone assays}

The jugular venous blood samples collected in fluoride EDTA tubes were analysed for glucose and insulin and those collected in heparin-lithium tubes were analysed for progesterone, oestradiol-17 $\beta$ and FSH. Samples of follicular fluid were assayed for oestradiol-17 $\beta$. All assays were carried out in duplicate.

\section{Glucose}

The concentration of glucose in plasma was determined by colourimetry using the glucose oxidase method (Glucose Assay Kit [cat \# G3660] and O-Dianisidine [cat \# D2679] Sigma Aldrich Inc., Saint-Quentin Fallavier, France). The assay method followed the instructions provided by the manufacturer of the kit. Plasma samples were diluted in phosphate buffered saline $(0.05 \mathrm{M}, \mathrm{pH} 7.6)$ as required, to obtain concentrations that fell within the range of the standard curve ( 2 to $8 \mathrm{mg}$ of glucose per $\mathrm{dL}$ ). The sensitivity of the assay was $2 \mathrm{mg} / \mathrm{dL}$ and the inter-assay 
and intra-assay coefficients of variation were $8 \%$ and $3 \%$ respectively.

\section{Insulin}

The concentration of insulin in plasma was measured using a heterologous radioimmunoassay developed in our laboratory [31]. The antiserum was rabbit anti-porcine insulin, the standards were ovine insulin and the second antibody was a goat anti-rabbit IgG (all reagents from Sigma Aldrich Inc., Saint-Quentin Fallavier, France). The sensitivity of the assay was $0.05 \mathrm{ng} / \mathrm{mL}$ and the inter-assay and intra-assay coefficients of variation were $10 \%$ and $15 \%$ respectively. The cross reactivity of the antiserum with ovine insulin was $100 \%$ relative to the homologous insulin standard.

\section{Oestradiol-17 $\beta$}

The concentration of oestradiol-17 $\beta$ in plasma was determined by the radioimmunoassay of solvent extracted plasma [32] using a commercial oestradiol assay kit (Estradiol-2 kit P2210; Diasorin, SA, Antony, France). The limit of detection of oestradiol was $0.39 \mathrm{pg} / \mathrm{mL}$ and the interand intra-assay coefficients of variation were $20.5 \%$ and $6.0 \%$ respectively. The concentrations of oestradiol- $17 \beta$ in samples of follicular fluid were determined using the same commercial oestradiol radioimmunoassay. Samples of follicular fluid were first diluted 1:10 or 1:100 in phosphate buffered saline $(0.05 \mathrm{M}, \mathrm{pH} 7.6)$ and assayed without solvent extraction. The concentration of oestradiol-17 $\beta$ in follicular fluid was derived using the theoretical volume of follicular fluid calculated as described [30], and corrected for dilution.

\section{Follicle stimulating hormone (FSH)}

The concentration of FSH in plasma was analysed using an ELISA [33]. The limit detection of FSH was $0.1 \mathrm{ng} / \mathrm{mL}$ the inter- and intra-assay coefficients of variation were $16.0 \%$ and $12.2 \%$ respectively.

\section{Progesterone}

The concentration of progesterone in plasma was determined using an ELISA [34]. The limit of detection of progesterone was $0.25 \mathrm{ng} / \mathrm{mL}$ the inter- and intra-assay coefficients of variation were $20.5 \%$ and $14.3 \%$ respectively.

\section{Antibodies for Western blotting}

All antibodies were obtained from commercial sources and their details are presented in Table 1 . The analysis of Akt used a rabbit polyclonal antibody to Akt (Cell Signalling Technology, Beverly, Ma., USA) and a rabbit polyclonal antibody to phospho-Akt1/2/3 (Ser473; Santa Cruz Biotechnology Inc., Heidelberg, Germany). The analysis of AMPK $\alpha 1 / 2$ used a rabbit polyclonal antibody to AMPK $\alpha 1 / 2$ (Cell Signalling Technology, Beverly Ma.,
USA) and a rabbit polyclonal antibody to phospho-AMPK (thr172; Cell Signalling Technology, Beverly, Ma., USA). The analysis of ERK2 used a polyclonal antibody to ERK2 (Cell Signalling Technology, Beverly, Ma., USA) and a polyclonal antibody to phospho-ERK1/2 (Thr202/Tyr204; Cell Signalling Technology, Beverly, Ma., USA). A mouse monoclonal antibody was used to analyse Aromatase $\mathrm{P}_{450}$ (ABD Serotec, Düsseldorf, Germany) and a mouse monoclonal antibody to vinculin was used as an internal standard (Sigma Aldrich Inc., Saint-Quentin Fallavier, France). All antibodies were used at a dilution of 1/1000 dilution. The secondary antibodies that were used depending on the species used to generate the primary antibody were either a goat anti-mouse IgG (Laboratories Eurobio, Courtaboeuf, France) or a goat anti-rabbit IgG (Laboratories Eurobio, Courtaboeuf, France).

\section{Western blotting}

Western blotting was used to determine the levels of Aromatase $\mathrm{P}_{450}$ protein relative to vinculin (an internal standard) in granulosa cell lysates from individual follicles greater than $2 \mathrm{~mm}$ in diameter [18], Aromatase $\mathrm{P}_{450}$ was not determined in small follicles. The levels of phosphorylated Akt and total Akt [18] were determined in granulosa cell lysates from individual follicles greater than $2 \mathrm{~mm}$ in diameter. The granulosa cells harvested from follicles between 1 and $2 \mathrm{~mm}$ in diameter were pooled within sheep. Similarly, the levels of phosphorylated AMPK and total AMPK [18] and the levels of phosphorylated ERK1/2 and total ERK2 were determined in granulosa cell lysates from individual follicles greater than $2 \mathrm{~mm}$ in diameter and in granulosa cells pooled within ewes from follicles between 1 and $2 \mathrm{~mm}$ in diameter. Lysates of granulosa cells were prepared as described [18] and then analysed by western blotting. The concentration of protein in the supernatants was determined by colourimetry using the BCA protein assay reagent (Interchim, Montluçon France). Aliquots of lysate containing $30 \mu \mathrm{g}$ of protein were re-suspended in Laemmli buffer (glycerol 50\%, SDS 10\%, Hepes 1 M-pH7.6, beta-Mercaptoethanol 25\%, bromophenol blue) and then analysed by western blotting.

Granulosa cell lysates were subjected to electrophoresis on $10 \%(\mathrm{v} / \mathrm{v})$ SDS-polyacrylamide gels for $2.5 \mathrm{~h}$ at $80 \mathrm{~V}$, in the running buffer $\left(\mathrm{H}_{2} \mathrm{O}_{2}, 50 \mathrm{mM}\right.$ Tris Base, $400 \mathrm{mM}$ Glycine, 2\% EDTA $0.1 \mathrm{M}, 1 \%$ SDS 10\%). The proteins were then transferred onto nitrocellulose membranes for $1.5 \mathrm{~h}$ at $80 \mathrm{~V}$, in transfer buffer $\left(\mathrm{H}_{2} \mathrm{O}_{2}, 20 \mathrm{mM}\right.$ Tris Base, $200 \mathrm{mM}$ Glycine, 20\% Methanol, 0.1\% SDS 10\%). After washing in TBS Tween $\left(\mathrm{H}_{2} \mathrm{O}_{2}, 2 \mathrm{mM}\right.$ Tris Base, $15 \mathrm{mM}$ $\mathrm{NaCl}, 0.1 \%$ Tween 20, pH 7.4), the membranes were incubated for $1 \mathrm{~h}$ at room temperature with TBS Tween containing $5 \%$ dry milk powder to saturate non-specific sites. Subsequently, membranes were incubated overnight 
Table 1 Details of the primary and secondary antibodies used for western immuno-blotting in this experiment

\begin{tabular}{|c|c|c|c|c|}
\hline Antibody & Type of antibody & Species & Source & Final dilution \\
\hline \multirow[t]{8}{*}{ Primary } & Anti-cytochrome ${ }_{\mathrm{p} 450}$ Aromatase $\mathrm{P}_{50}$ & Mouse monoclonal & ABD Serotec, Cergy Pontoise, France & $1: 200$ \\
\hline & Anti-Akt & Rabbit polyclonal & Cell Signalling (OZYME), Saint Quentin Yvelines, France & $1: 1,000$ \\
\hline & Anti-phospho-Akt1/2/3 (Ser473)-R & Rabbit polyclonal & Santa Cruz Biotechnology, Tebu-Bio, Le Perray-en_ Yvelines & $1: 1,000$ \\
\hline & Anti-AMPK & Rabbit polyclonal & Cell Signalling (OZYME), Saint Quentin Yvelines, France & $1 / 1,000$ \\
\hline & Anti-phospho-AMPK Thr 172 & Rabbit polyclonal & Cell Signalling (OZYME), Saint Quentin Yvelines, France & $1: 1,000$ \\
\hline & Anti-Erk2 (C-14) & Rabbit polyclonal & Cell Signalling (OZYME), Saint Quentin Yvelines, France & $1: 1,000$ \\
\hline & Anti-phospho-ERK1/2 & Rabbit polyclonal & Cell Signalling (OZYME), Saint Quentin Yvelines, France & $1 / 1,000$ \\
\hline & Anti-vinculin & Mouse monoclonal & Sigma Aldrich, Saint-Quentin Fallavier, France & $1: 1,000$ \\
\hline \multirow[t]{2}{*}{ Secondary } & Anti-Mouse lgG & Goat polyclonal & Laboratoires Eurobio, Courtaboeuf, France & $1: 10,000$ \\
\hline & Anti-Rabbit lgG & Goat polyclonal & Laboratoires Eurobio, Courtaboeuf, France & $1: 10,000$ \\
\hline
\end{tabular}

at $4^{\circ} \mathrm{C}$ with primary antibodies in TBS Tween containing $5 \%$ dry milk powder.

After washing in TBS Tween, the membranes were incubated with a horseradish peroxidase (HRP)-conjugated anti-rabbit IgG (Final dilution 1:10 000; Laboratories Eurobio, Courtaboeuf, France) or horseradish peroxidase (HRP)-conjugated anti-mouse IgG (Final dilution 1:10,000; Laboratories Eurobio, Courtaboeuf, France) for $2 \mathrm{~h}$ at room temperature in TBS Tween containing $5 \%$ dry milk powder. After washing in TBS Tween, the signal was detected by enhanced chemiluminescence (PerkinElmer, Life and Analytical Sciences, Courtaboeuf, France). The membranes were exposed on GE Healthcare film (PerkinElmer, Life and Analytical Sciences, Courtaboeuf, France), and then developed (Kodak AL4) and fixed (Kodak LX24) and dried. The films were analysed and the blots quantified using ScionImage (4.0.3.2 version, Scion Corporation, Frederick, Maryland, USA).

\section{Statistical analysis}

Statistical analyses were performed using specialised software for statistical analysis (SAS Statview version 5.0). Data on hormone concentrations in plasma and body weight were analysed by repeated measures ANOVA with time as the repeated measure. Where it was appropriate, post-hoc paired comparisons within time were carried out using the Bonferroni test. Other data were analysed by univariate ANOVA apart from the data on follicle number which were analysed using the Chi-squared test. The data are presented as the mean \pm sem and differences are regarded as significant when $\mathrm{P}<0.05$.

\section{Results}

In a ewe from a glucose-infused group the catheter failed and the infusion was interrupted. This animal was excluded from the experiment.

\section{Body weight}

The average weights in the group infused with glucose at the start of the infusion and at ovariectomy were $47.0 \pm 0.72$ and $45.6 \pm 0.78 \mathrm{~kg}$, respectively. The average weights in the control group at the start of infusion, and at ovariectomy were $48.0 \pm 0.73$ and $46.0 \pm 0.84 \mathrm{~kg}$, respectively. There were no significant differences in the average weights within or between groups.

\section{Ovarian morphology}

The ewes in the two luteal phase groups had $3.11 \pm 0.80$ functional corpora lutea (CLs) in the glucose-infused group and $2.89 \pm 0.58 \mathrm{CLs}$ in the control group, confirming that the ewes were as expected, in the luteal phase of the oestrous cycle. The numbers of follicles dissected from the ovaries of control and glucose infused ewes are shown in Table 1 . There were significantly more small follicles in the glucose-infused groups compared to controls at the same stage of the oestrous cycle (Table 2) and this is reflected also in the total number of follicles. There were no differences in follicle numbers between stages of the oestrous cycle and the number of medium and large follicles was not different between glucoseinfused and control ewes (Table 2).

\section{Plasma concentrations of metabolites Glucose}

The concentrations of glucose in plasma are shown in Figure 2, overall there was a significant effect $(P=0.001)$ of treatment on the concentration of glucose. The plasma concentration of glucose was significantly elevated by $3 \mathrm{~h}$ $(\mathrm{P}<0.01)$ after the start of the infusion of glucose and remained elevated at $9 \mathrm{~h}(\mathrm{P}<0.01)$, at $24 \mathrm{~h}(\mathrm{P}<0.01)$ and at $48 \mathrm{~h}(\mathrm{P}<0.05)$ but, it had decreased to control concentrations at $72 \mathrm{~h}$. The concentration of plasma glucose in control ewes did not vary significantly during the experiment (Figure 2). 
Table 2 Corpora lutea (CLs) and follicles

\begin{tabular}{lcccccc}
\hline Phase & Treatment & CLs & \multicolumn{3}{c}{ Follicles } \\
\cline { 3 - 6 } & & & Small & Medium & Large & Total \\
\hline Glucose $(\boldsymbol{n}=\mathbf{1 7})$ & Follicular $(n=8)$ & $2.4 \pm 0.32$ & $26.0 \pm 1.92^{\mathrm{a}}$ & $7.9 \pm 0.78$ & $2.0 \pm 0.53$ & $36.9 \pm 3.57^{\mathrm{a}}$ \\
& Luteal $(n=9)$ & $3.1 \pm 0.8$ & $27.2 \pm 3.65^{\mathrm{a}}$ & $10.8 \pm 1.52$ & $1.9 \pm 0.42$ & $39.9 \pm 4.43^{\mathrm{a}}$ \\
Saline $(\boldsymbol{n}=\mathbf{1 8})$ & Follicular $(n=9)$ & $1.8 \pm 0.32$ & $16.2 \pm 0.99^{\mathrm{b}}$ & $6.9 \pm 1.85$ & $2.1 \pm 0.48$ & $25.5 \pm 1.49^{\mathrm{b}}$ \\
& Luteal $(n=9)$ & $2.9 \pm 0.58$ & $13.1 \pm 1.67^{\mathrm{b}}$ & $10.1 \pm 1.29$ & $1.9 \pm 0.45$ & $25.1 \pm 2.78^{\mathrm{b}}$ \\
\hline
\end{tabular}

The mean \pm SEM, number of corpora lutea (CLs) and follicles classified by diameter as small ( 1 to $<2 \mathrm{~mm}$ ) medium $(2$ to $<3.5 \mathrm{~mm})$ and large $(>3.5 \mathrm{~mm})$ of ewes during the follicular and luteal phases of the oestrous cycle and following a $72 \mathrm{~h}$ infusion of saline or glucose $(10 \mathrm{mM} / \mathrm{h})$. Within columns, values with different superscripts $(a, b)$ are significantly different at $\mathrm{P}<0.05$.

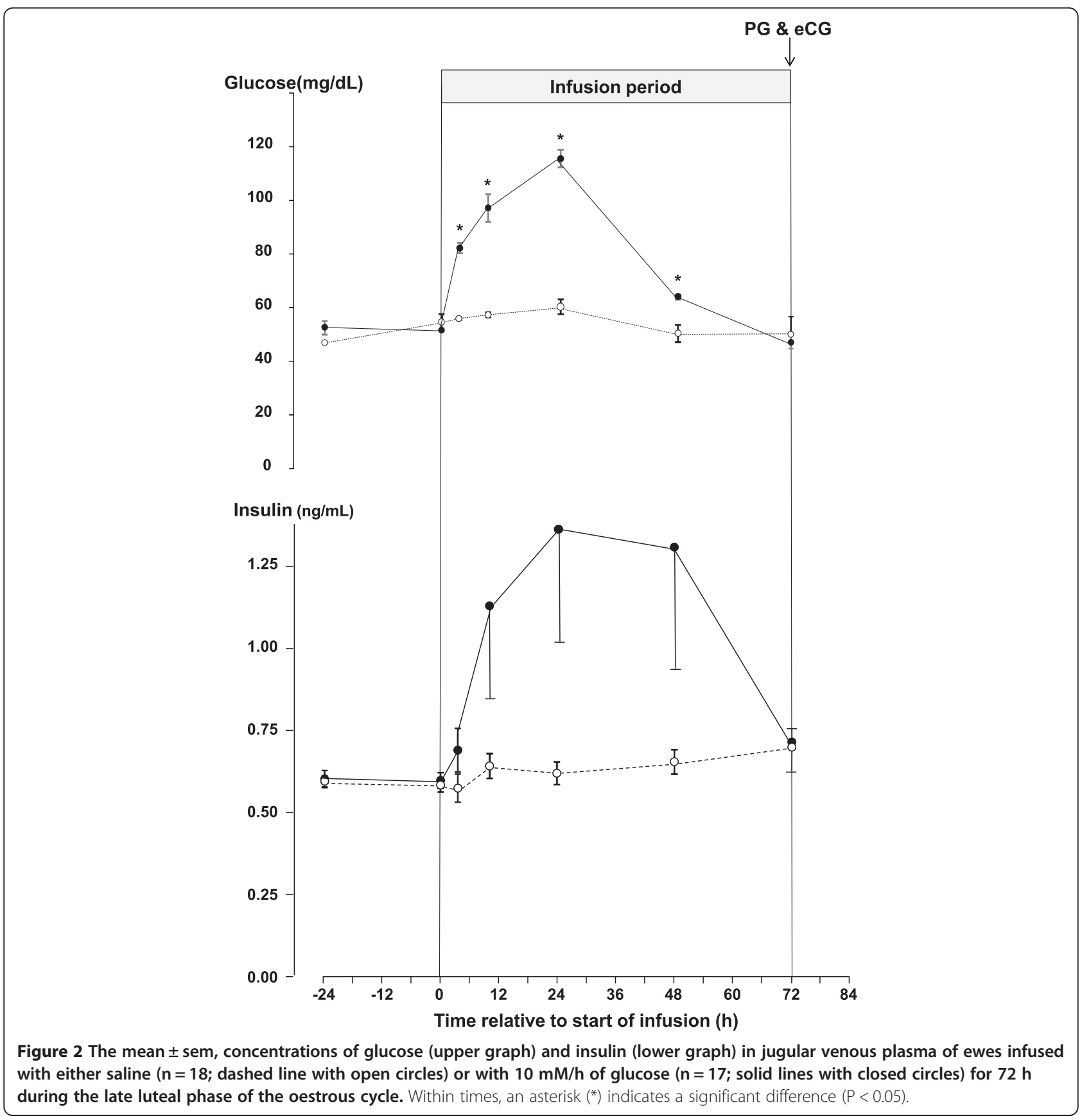




\section{Insulin}

The plasma concentrations of insulin are shown in Figure 2, overall there was a significant effect $(P=0.02)$ of treatment on the concentration of insulin. Paired comparisons revealed that the concentration of insulin was significantly elevated by $9 \mathrm{~h}(\mathrm{P}<0.05)$ after the start of the infusion of glucose and remained elevated at $24 \mathrm{~h}$ $(\mathrm{P}<0.01)$ and at $48 \mathrm{~h}(\mathrm{P}<0.05)$ but, it had decreased to control concentrations at $72 \mathrm{~h}$. The concentration of insulin in control ewes did not vary significantly during the experiment (Figure 2).

\section{Plasma concentrations of reproductive hormones Oestradiol-17 $\beta$}

The plasma concentrations of oestradiol-17 $\beta$ are shown in Figure 3 . The pre-treatment concentrations of plasma oestradiol were not significantly different between the glucose and control groups. However, the plasma concentration of oestradiol was reduced in the glucoseinfused groups compared to the control group $(\mathrm{P}<0.05)$ during the infusion period between 6 and $66 \mathrm{~h}$ after the start of the infusions. There was also a significant effect of time $(\mathrm{P}<0.05)$ following luteolysis; the plasma concentration of oestradiol increased significantly in both groups and by $12 \mathrm{~h}$ after PG the glucose-infused group was no longer lower than the control group (Figure 3).

\section{Follicle stimulating hormone (FSH)}

The concentration of FSH in plasma $(0.72 \pm 0.040 \mathrm{ng} / \mathrm{mL})$ from glucose-infused ewes was not different from that in control ewes $(0.67 \pm 0.036 \mathrm{ng} / \mathrm{mL})$. There was a significant effect of time and the concentration of FSH fell

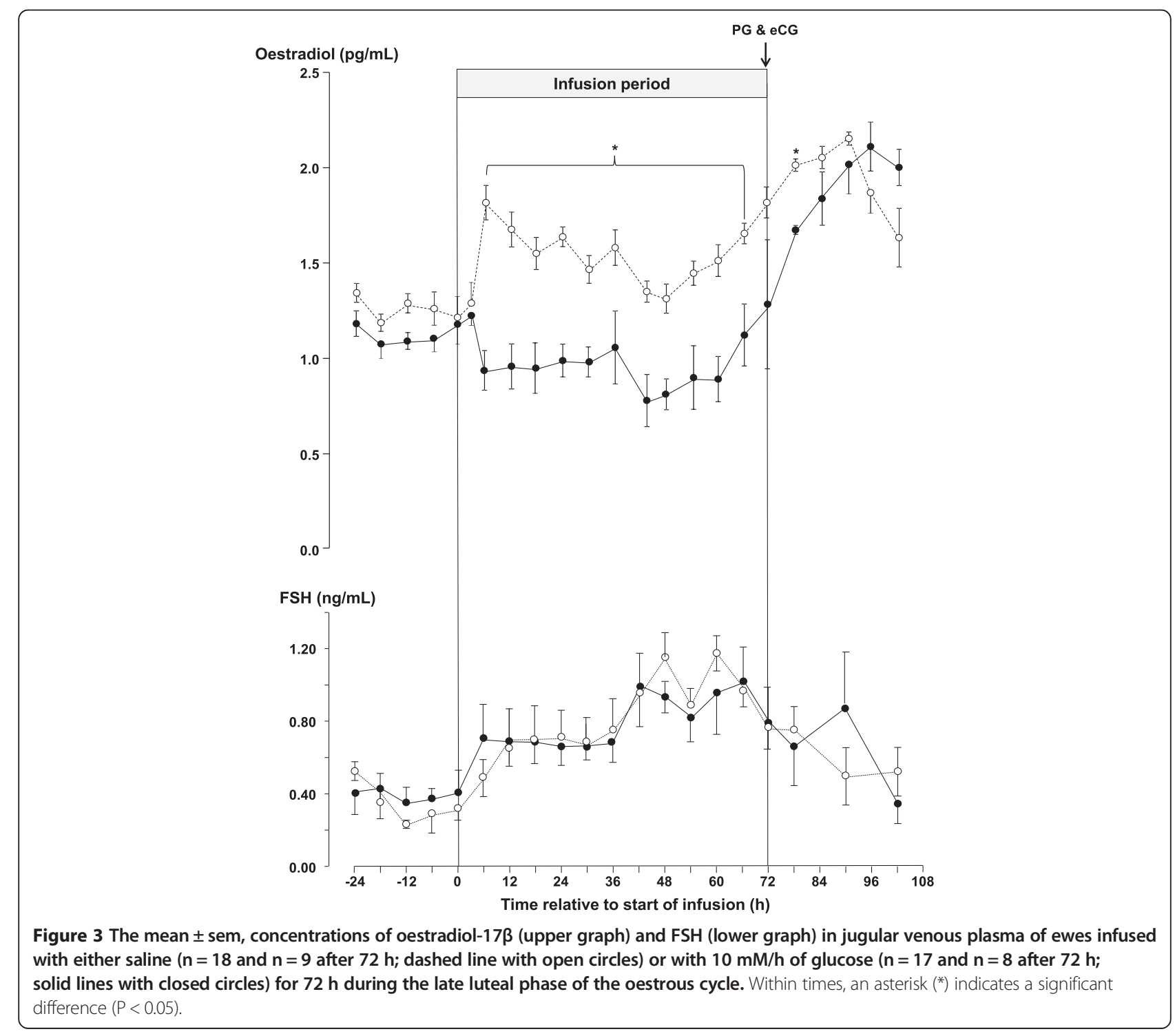


significantly following the induction of luteolysis (Figure 3) but, the interaction between time and treatment was not significant.

\section{Progesterone}

The profiles of progesterone in plasma (all concentrations above $2 \mathrm{ng} / \mathrm{mL}$ prior to the injection of PG and falling to below $1 \mathrm{ng} / \mathrm{mL}$ by $30 \mathrm{~h}$ after PG) confirmed that all ewes were undergoing normal oestrous cycles and that they were at the correct stage of the oestrous cycle at the time the ovaries were collected.

\section{Concentrations of oestradiol in follicular fluid}

The concentrations of oestradiol in follicular fluid are shown in Figure 4. The concentration of oestradiol in oestrogenic follicles was significantly higher compared to non-oestrogenic follicles from all three follicle classes $(\mathrm{P}<0.05)$ and in the follicular phase compared to the luteal phase of the oestrous cycle $(\mathrm{P}<0.05$; Figure 4$)$. The concentration of oestradiol did not differ significantly among follicle classes in non-oestrogenic follicles but, in oestrogenic follicles the concentration of oestradiol was higher in medium follicles compared to small follicles $(\mathrm{P}<0.001)$ and higher in large follicles compared to medium $(\mathrm{P}<0.001)$ and small follicles $(\mathrm{P}<0.001$; Figure 4$)$. Finally the infusion of glucose reduced the concentration of oestradiol in large $(\mathrm{P}<0.001)$ oestrogenic follicles collected during the follicular phase of the oestrous cycle and in both medium $(\mathrm{P}<0.001)$ and large $(\mathrm{P}<0.001)$ oestrogenic follicles collected in the luteal phase of the oestrous cycle (Figure 4). Glucose had no effect in nonoestrogenic follicles (Figure 4).

\section{Aromatase $\mathbf{P}_{450}$}

The levels of Aromatase $\mathrm{P}_{450}$ protein in granulosa cells are shown in Figure 5. In oestrogenic follicles Aromatase $\mathrm{P}_{450}$ was significantly $(\mathrm{P}<0.05)$ higher in the follicular phase compared to the luteal phase in both medium and large follicles. The levels of Aromatase $\mathrm{P}_{450}$ were significantly $(\mathrm{P}<0.05)$ lower in non-oestrogenic follicles compared to oestrogenic follicles regardless of their size (Figure 5). The infusion of glucose significantly $(\mathrm{P}<0.05)$ reduced the level of Aromatase $\mathrm{P}_{450}$ in oestrogenic follicles of all sizes but, it had no effect on the level of Aromatase $\mathrm{P}_{450}$ in non-oestrogenic follicles (Figure 5). In non-oestrogenic follicles Aromatase $\mathrm{P}_{450}$ did not vary significantly with either the stage of the oestrous cycle or the diameter of the follicle.

\section{Mediators of Insulin-signalling (Akt, ERK and AMPK)}

The ratios of phosphorylated to non-phosphorylated forms of Akt (Figure 6), ERK (Figure 7) and AMPK (Figure 8) were all lower (all at $\mathrm{P}<0.05$ ) in non-oestrogenic follicles compared to oestrogenic follicles while in non-oestrogenic follicles the ratios for all three were unaffected by the diameter of the follicle, the stage of the oestrous cycle or the infusion of glucose (Figures 6, 7 and 8). However, in oestrogenic follicles the infusion of glucose reduced the ratio of phosphorylated non-phosphorylated forms of all three compared to control ewes in medium and large follicles from the luteal phase (all at $\mathrm{P}<0.05$ ) and in all three follicle classes in follicles from the follicular phase ( $\mathrm{P}<0.05$; Figures 6,7 and 8 ). Similarly, the ratios for all three were not significantly different in small and medium follicles and they were significantly higher in large follicles (all at $\mathrm{P}<0.05$ ) compared to small and medium follicles
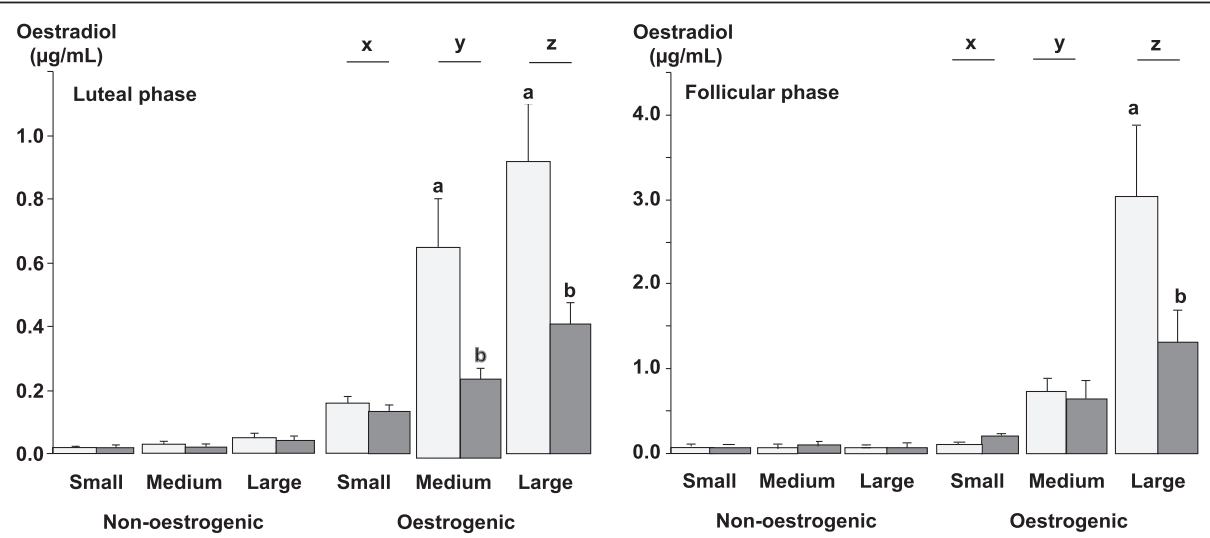

Figure 4 The mean \pm sem, concentrations of oestradiol- $17 \beta$ in follicular fluid from small $(<2.0 \mathrm{~mm})$, medium $(2.0$ to $3.5 \mathrm{~mm})$ and large $(>3.5 \mathrm{~mm}$ ) diameter oestrogenic (oestradiol $>100 \mathrm{ng} / \mathrm{mL}$ ) and non-oestrogenic (oestradiol $<100 \mathrm{ng} / \mathrm{mL}$ ) follicles from ewes during the luteal and follicular phases of the oestrous cycle infused with saline (light grey columns) or with $10 \mathrm{mM} / \mathrm{h}$ of glucose (dark grey columns) for $\mathbf{7 2} \mathbf{h}$ during the late luteal phase of the oestrous cycle. Follicle classes with different letters $(x, y$ and $z)$ differ significantly at $P<0.05$. Note there is a difference in scale between the luteal and follicular phase diagrams. 


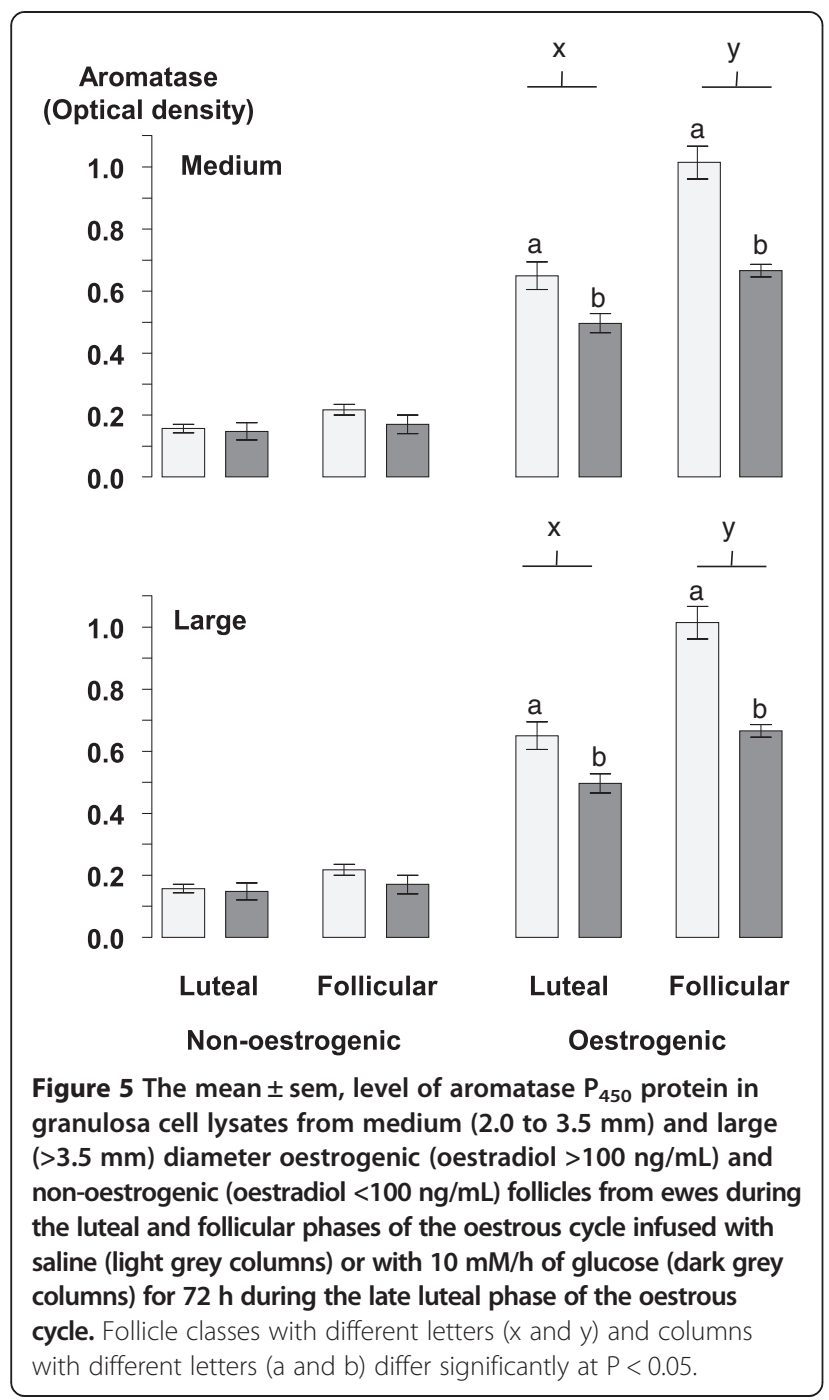

(Figures 6, 7 and 8). There were no significant differences between the follicular and luteal phases between follicle types or among follicle diameters.

\section{Discussion}

The results of this experiment show that in cyclic ewes during the breeding season, the intravenous infusion of glucose increased the total number of follicles present in their ovaries [17]. These findings agree with those obtained when using anoestrous ewes treated with eCG [18]. Furthermore the present experiment also shows that the effect of intravenous glucose on the follicle population of the ovary is present in both the luteal and follicular phases of the oestrous cycle. The concentrations of glucose achieved by the infusions peaked at $120 \mathrm{mg} / \mathrm{dL}$ or about $30 \%$ above the upper limit of the normal reference range for sheep (45-80 mg/dL). Additionally, this effect of glucose was also associated with a reduction in the circulating concentrations of oestradiol (Figure 3) but without any associated

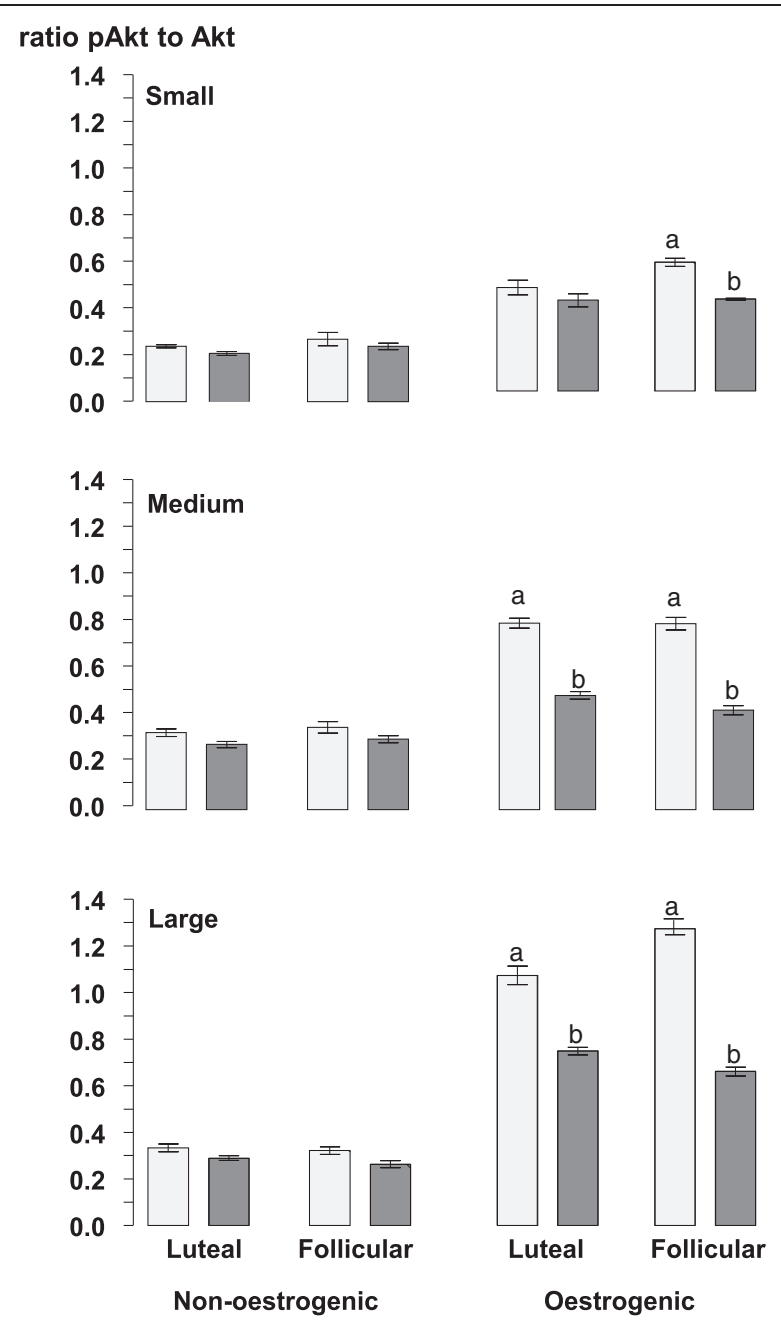

Figure 6 The mean \pm sem, ratios of phosphorylated to non-phosphorylated Akt in granulosa cell lysates from small $(<2.0 \mathrm{~mm})$, medium $(2.0$ to $3.5 \mathrm{~mm})$ and large $(>3.5 \mathrm{~mm})$ diameter oestrogenic (oestradiol $>100 \mathrm{ng} / \mathrm{mL}$ ) and non-oestrogenic (oestradiol $<100 \mathrm{ng} / \mathrm{mL}$ ) follicles from ewes during the luteal and follicular phases of the oestrous cycle infused with saline (light grey columns) or with $10 \mathrm{mM} / \mathrm{h}$ of glucose (dark grey columns) for $72 \mathrm{~h}$ during the late luteal phase of the oestrous cycle. Columns with different letters ( $a$ and $b$ ) differ significantly at $P<0.05$.

change in the concentrations of circulating FSH (Figure 3) and a reduction in the level of ovarian Aromatase $\mathrm{P}_{450}$ in oestrogenic follicles (Figure 5). Furthermore, the effect of glucose was accompanied by an increase in the circulating concentration of insulin (Figure 2) and finally it was associated with changes in the insulin signalling and energy sensing mechanisms (Figures 6, 7 and 8) in granulosa cells.

Very similar findings have been reported for the effects of diets that increase the supply of energy. Feeding dietary supplements such as lupin grain [13,17,20,35,36], a mixture of soya meal and maize [14], or steamed corn flakes [37] or administering by gavage, an energy supplement in the form of a mixture of glycerol and propylene glycol 


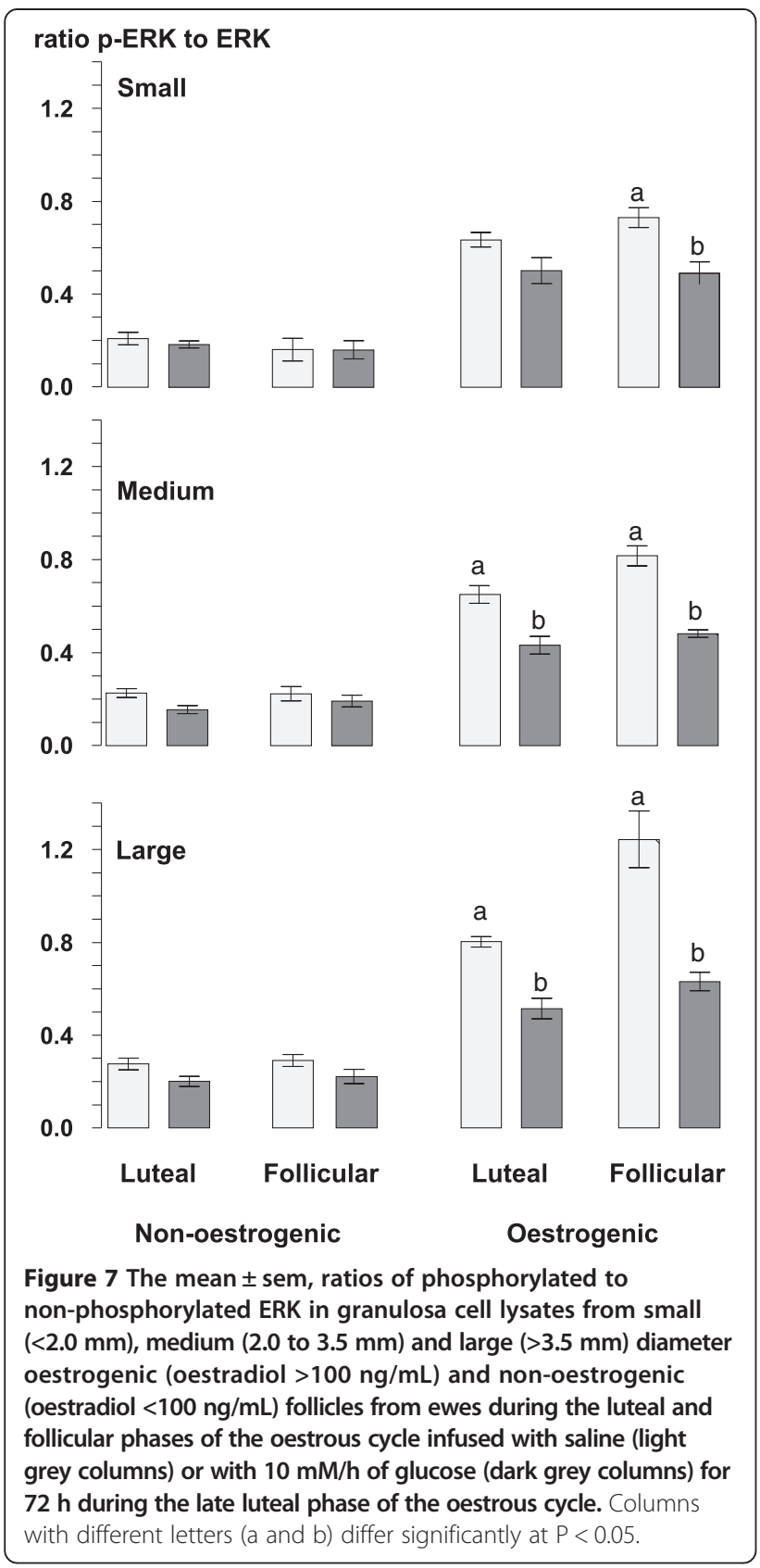

$[38,39]$ to ewes all increased the number of follicles in their ovaries. In all these studies the nutritional treatment increased the concentrations of glucose and insulin in jugular venous plasma and these changes were associated with an increased number of follicles. Some of these studies also reported reduced concentrations of oestradiol in jugular plasma [20,35], reduced levels of Aromatase $\mathrm{P}_{450}$ in granulosa cell lysates $[13,20]$ and lower concentrations of oestradiol in follicular fluid from oestrogenic follicles $[13,20]$.

There is some controversy over the effects of either glucose or glucogenic diets on the circulating concentrations

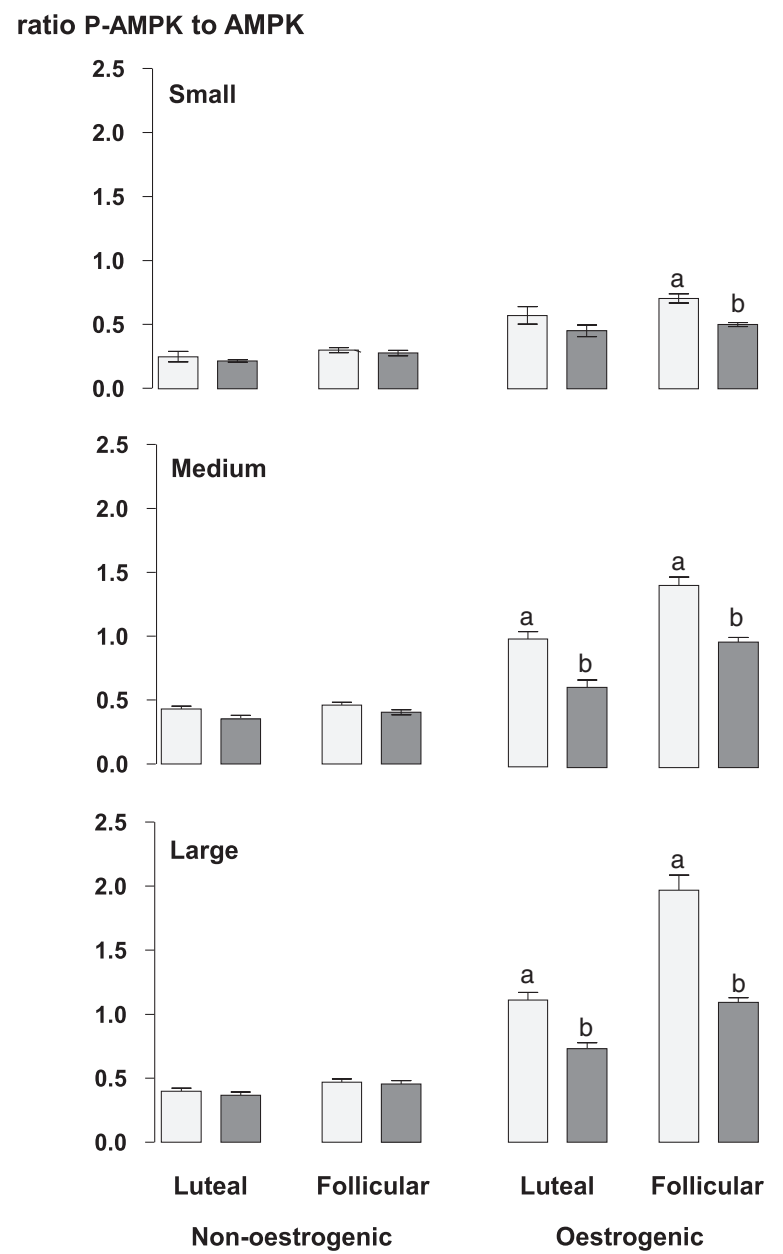

Figure 8 The mean \pm sem, ratios of phosphorylated to non-phosphorylated AMPK in granulosa cell lysates from small $(<2.0 \mathrm{~mm})$, medium $(2.0$ to $3.5 \mathrm{~mm})$ and large $(>3.5 \mathrm{~mm}$ ) diameter oestrogenic (oestradiol $>100 \mathrm{ng} / \mathrm{mL}$ ) and non-oestrogenic (oestradiol $<100 \mathrm{ng} / \mathrm{mL}$ ) follicles from ewes during the luteal and follicular phases of the oestrous cycle infused with saline (light grey columns) or with $10 \mathrm{mM} / \mathrm{h}$ of glucose (dark grey columns) for $72 \mathrm{~h}$ during the late luteal phase of the oestrous cycle. Columns with different letters ( $a$ and $b$ ) differ significantly at $P<0.05$.

of oestradiol. We have reported decreased circulating concentrations of oestradiol following the infusion of glucose [18] or the feeding of a lupin grain supplement [20] and other authors have reported similar findings [35]. However other studies from our group found that feeding lupin grain [13] had no effect on oestradiol and other authors have also found no effect of glucogenic diets on the concentrations of oestradiol in jugular venous blood [14]. Using a different experimental model, these authors also reported that a supplement of lupin grain increased oestradiol concentrations and reduced those of FSH [36]. The main reason for these discrepancies is most probably because sheep have particularly low concentrations of oestradiol [40] and the oestradiol assays 
employed are being used at the very limits of their technical capability. The secretion rate of oestradiol was reduced by feeding a lupin grain supplement to ewes with ovarian auto-transplants [3] and in other experiments the concentration of oestradiol in the follicular fluid was reduced by feeding a supplement of lupin grain $[13,20]$ or a high energy diet [41] and in this experiment the infusion of glucose reduced the concentration of oestradiol in the follicular fluid of oestrogenic follicles (Figure 4). Furthermore these treatments were associated with reduced levels of Aromatase $\mathrm{P}_{450}$ in granulosa cell lysates from oestrogenic follicles $[13,18,20,42]$. So on balance we conclude tentatively, that it is very likely that both intravenous glucose and glucogenic diets can reduce the secretion of follicular oestradiol from oestrogenic follicles.

The effect of glucose on ovarian follicles appears to be dependent on the stage of development of the follicles. In the population of small follicles the effect of glucose was to stimulate their growth a conclusion that can be inferred from the increased number of small follicles in glucose-infused ewes (Table 2). Furthermore in small non-oestrogenic follicles this effect was not associated with any detectable change in the level of phosphorylated Akt, ERK1/2 and AMPK (Figures 6, 7 and 8) suggesting that this effect of glucose was not related to altered activity of insulin-signalling pathways in granulosa cells. This leads us to conclude that it is was possibly a direct effect of an increased supply of metabolic fuel (glucose) to the ovary. By contrast, in medium and large follicles glucose had little effect on the number of follicles (Table 2) but, in medium and large oestrogenic follicles it did have substantial effects on their physiological function through an inhibition of the level of aromatase $\mathrm{P}_{450}$ (Figure 5) and a reduction in the concentration of oestradiol in follicular fluid (Figure 4). These actions were associated with changes in insulin signalling pathways and so these follicles are presumed to be responsive to both insulin and glucose and that the effect of glucose is insulin-mediated [43].

Extrapolating further, these data indicate that oestrogenic follicles are insulin-responsive [43] and that non-oestrogenic follicles are not. The population of non-oestrogenic follicles is a mixed population consisting of a sub-population of undifferentiated, small growing follicles and a sub-population of medium and large atretic follicles neither of which are insulin-responsive. Our findings suggest that glucose acts directly in growing follicles to stimulate growth leading to greater numbers of small follicles while in oestrogenic follicles which are physiologically functional but non-growing, glucose acts indirectly through an insulin-mediated mechanism to inhibit the synthesis and secretion of oestradiol [43].

The circulating concentration of IGF-I was not determined in this experiment. However, it was in our earlier experiment [18] where glucose increased the jugular venous concentrations of IGF-I. Despite the fact that IGFI is a potent stimulator of both follicle growth [29] and oestradiol secretion $[29,44]$ we consider it unlikely that the effects of glucose in the follicle, in this experiment were mediated by IGF-I. IGF-I is a potent growth factor controlled by hepatic feedback systems that are independent of ovarian follicles [45]. Consequently there are intra-ovartian mechanisms that regulate the activity of IGF-I $[46,47]$ to protect the follicle from the potentially harmful effects of high concentrations of IGF-I. None-theless it is possible that the insulin-independent effects of glucose on small follicles (Table 2) are an effect of IGF-I. Interestingly, glucose reduced circulating (Figure 3) and intrafollicular (Figure 4) concentrations of oestradiol suggesting that the intra-follicular bio-activity of IGF-I in oestrogenic follicles is suppressed.

The expected effect of reduced secretion of oestradiol (Figure 3) would be an increase in circulating FSH. How then can we explain the absence of the expected compensatory increase in FSH? Published data on the effects of glucogenic diets on the plasma concentrations of FSH presents a mixed picture. Some authors have reported increased concentrations of FSH and others have reported no change. It has been suggested that the reasons for these differences are technical and associated with the assays employed to measure ovine FSH [45] or that they reflect the dynamic nature of the negative relationship between FSH and the follicle [3]. However, it is also possible that the variation simply indicates the presence of uncontrolled and unidentified physiological differences among animals leading to unconscious bias in randomisation procedures. In an attempt to control this variability, Vinoles and her colleagues [36] used a first wave model to synchronise follicles waves and thus theoretically, reduce between ewe variability in the follicle population. Their results showed that supplementation with a glucogenic diet increased concentrations of oestradiol and reduced those of FSH in jugular plasma. However, the control of FSH by negative feedback from the ovary has two hormonal components namely oestradiol and inhibin and until the effects of glucogenic diets on the secretion of ovarian inhibin have been described a complete understanding of the effects of glucogenic diets on FSH will not be possible. Regrettably, at present there in no satisfactory technique available for measuring the concentration of inhibin in jugular venous plasma from sheep.

It is worth noting that the population of small growing follicles is an important source of inhibin [48]. Because glucogenic diets increase their number then theoretically, these diets should also increase the total secretion of follicular inhibin and the concentration of inhibin in the peripheral circulation. We can speculate that the resulting increase in inhibin negative feedback on FSH may thus compensate for any reduced oestradiol feedback and may 
explain why in some studies oestradiol decreased but FSH did not increase. We suggest that variability of the FSH responses to glucogenic treatments may reflect subtle changes in the balance of the effects of glucogenic diets on small growing (i.e. inhibin secreting) and large oestrogenic (i.e. oestradiol secreting) follicles.

The follicle has a functional insulin-glucose system [5] and the level of activity in the pathway can be estimated from the ratio of phosphorylated to non-phosphorylated forms of the various protein kinases in the pathway. Some of the kinases activated by insulin, although not exclusively, including Akt, ERK and AMPK have been detected in ovarian follicles from ewes [18,49-52] and in this experiment the phosphorylation ratios of all three of these were altered by the infusion of glucose. The Irish group [49-51] have shown that both Akt and ERK are implicated in the mechanism of follicle selection and this study confirms their findings [18] showing that intravenous glucose decreased the level of phosphorylation of Akt and AMPK and furthermore, shows for the first time that glucose reduced the level of phosphorylation of ERK. How do these effects relate to the mechanism through which a glucogenic diet can increase ovulation rate? Ovulation rate in sheep is ultimately determined by the number of gonadotrophin-dependent, ovulatory follicles present at the time of the LH surge. The reduction in the secretion of oestradiol by the ovulatory follicle suggests that the effect of glucose is to impair FSH-stimulated synthesis of oestradiol, the reduced levels of Aromatase $\mathrm{P}_{450}$ are consistent with such an action, and reduce its inhibitory influence (or dominance) on subordinate follicles in the cohort thus allowing for the emergence of additional ovulatory follicles. Potential mechanisms probably involve "cross-talk" [53] between the insulin signalling and FSH signalling pathways in granulosa and theca cells of the ovulatory follicle [5]. However, the details of how and where these signalling pathways interact are topics for future research.

\section{Conclusions}

These results show that an intravenous glucose that maintains the concentration of blood glucose slightly above the upper end of the normal reference range increased the number of small follicles and altered the function of follicular granulosa cells in large oestrogenic follicles but not in small follicles or non-oestrogenic follicles of any size. The glucose reduced the levels of Aromatase $P_{450}$ in large oestrogenic follicles and this was reflected in a reduced blood concentration of oestradiol. These reduced levels of Aromatase $\mathrm{P}_{450}$ were associated with reduced levels of phosphorylated Akt, ERK and AMPK in large follicles. However, glucose did not affect the phosphorylation state of the energy sensor, AMPK and mediators of insulin action (Akt, ERK) in small follicles. These data suggest that the effect of glucose in small follicles is a direct action of glucose that increases the number of small follicles while the effect of glucose in large, oestrogenic follicles is an indirect insulin-mediated action that inhibits their capacity to secrete oestradiol.

\section{Abbreviations}

Akt: A Protein kinase B; AMPK: 5' adenosine monophosphate-activated kinase; ANOVA: Analysis of variance; BCA: Bicinchoninic acid; CL: Corpus luteum; eCG: equine chorionic gonadotrophin; EDTA: Ethylenediaminetetra acetic acid; ELISA: Enzyme linked immunosorbent assay; ERK: Extra cellular-related protein kinase; FSH: Follicle stimulating hormone; GH: Growth hormone; GLUT 4: Glucose transporter 4; IGF-l: Insulin-like growth factor 1; IgG: Immunoglobulin G; INRA: L'Institut National de la Recherche Agronomique; IRS: Insulin receptor substrate; LH: Luteinizing hormone; PGF $_{2 a}$ : Prostaglandin $F_{2 a}$; SDS: Sodium dodecyl sulphate; Sem: Standard error of the mean; SLC2A-4: Sugar transport facilitator; TBS: Tris-buffered saline.

\section{Competing interests}

The authors declare that they have no competing interest.

\section{Authors' contributions}

J-BM developed and carried out the immunoassay for insulin and participated in management of the animals, the collection of plasma and tissue samples and drafting the manuscript. JD participated in the design of the study and drafting the manuscript and advised on the western blotting procedure. RJS conceived of the study and participated in its design and coordination and drafted the manuscript and advised on the statistical analysis. NZ participated in the design of the study and carried out management of the animals, the collection of plasma and tissue samples, the laboratory procedures, and the statistical analysis and participated in drafting the manuscript. All authors read and approved the final manuscript.

\section{Acknowledgements}

The research was supported by a grant from the European Union Framework 6 funding program (MEXC-CT-2006-042499). NZ was supported by scholarships from the Tunisian government and INRA. RJS was the recipient of an EU Marie Curie Chair of Excellence (MEXC-CT-2006-042499). We wish to thank Mrs Juliette Cognié for carrying out the ovariectomies, Mr Lionel Lardic for the oestradiol assays, Dr Danielle Monniaux and Dr Sandrine Freret for help with the ovarian dissections, the staff from the INRA experimental station at Nouzilly for their help with experimental animals and Anne-Lyse Laine of the hormone assay laboratory of the UMR PRC for the assays of progesterone and FSH.

\section{Author details}

'L'Institut National de la Recherche Agronomique, Unité Mixte de Recherche 6175, Physiologie de la Reproduction et des Comportements, Nouzilly 37380, France. ${ }^{2}$ Department of Comparative Biomedical Sciences, The Royal Veterinary College, Hawkshead Lane, North Mimms, Hertfordshire AL9 7TA, UK. ${ }^{3}$ Present address: L'Institut National de la Recherche Agronomique, UR 1213 URH Unité de Recherches sur les Herbivores, Centre de recherche de Clermont-Ferrand-Theix, Clermont-Ferrand, France.

Received: 22 October 2014 Accepted: 17 January 2015 Published: 20 January 2015

\section{References}

1. Lindsay DR. The usefulness to the animal producer of research findings in nutrition on reproduction. Proc Aust Soc Anim Prod. 1976;11:217-24.

2. Lindsay DR, Martin GB, Williams $\mid H$. Nutrition and reproduction. In: King GJ, editor. Reproduction in Domesticated Animals. Amsterdam: Elsevier; 1993. p. 459-91.

3. Scaramuzzi RJ, Campbell BK, Downing JA, Kendall NR, Khalid M, MuñozGutiérrez $M$, et al. A review of the effects of supplementary nutrition in the ewe on the concentrations of reproductive and metabolic hormones and the mechanisms that regulate folliculogenesis and ovulation rate. Reprod Nut Dev. 2006;46:339-54. 
4. Downing JA, Scaramuzzi RJ. Nutrient effects on ovulation rate, ovarian function and the secretion of gonadotrophic and metabolic hormones in sheep. J Reprod Fertil Suppl. 1991;43:209-27.

5. Scaramuzzi RJ, Brown HM, Dupont J. Nutritional and metabolic mechanisms in the ovary and their role in mediating the effects of diet on folliculogenesis: A perspective. Reprod Dom Anim. 2010;45 Suppl 3:32-41.

6. Dupont J, Scaramuzzi RJ, Reverchon M. The effect of nutrition and metabolic status on the development of follicles, oocytes and embryos in ruminants. Animal. 2014;2014(28):1-14.

7. Gherardi PB, Lindsay DR. Response of ewes to lupin supplementation at different times of the breeding season. Aust J exp Agric Anim Husb. 1982;1982(22):264-7.

8. Nottle MB, Setchell BP, Seamark RF. Supplementation with lupin grain for 6 days can increase induced ovulation rate in ewes. Proc Nut Soc Aust. 1986;11:s139.

9. Stewart R, Oldham CM. Feeding lupins to ewes for four days during the luteal phase can increase ovulation rate. Anim Prod Aust. 1986;16:367-9.

10. Teleni E, Rowe JB, Croker KP, Murray PJ, King WR. Lupins and energy-yielding nutrients in ewes $\|$ Responses in ovulation rate in ewes to increased availability of glucose, acetate and amino acids. Reprod Fert Dev. 1989;1:117-25.

11. Downing JA, Joss J, Connell P, Scaramuzzi RJ. Ovulation rate and the concentrations of gonadotrophic and metabolic hormones in ewes fed lupin grain. J Reprod Fert. 1995;103:137-45.

12. Muñoz-Gutiérrez M, Blache D, Martin GB, Scaramuzzi RJ. Ovarian follicular expression of mRNA encoding the type I insulin like growth factor receptor (IGF-IR) and insulin like growth factor binding protein 2 (IGFBP2) in anoestrous sheep after 5 days of glucose or glucosamine or supplementary feeding with lupin grain. Reproduction. 2004;128:1-11.

13. Somchit A, Khalid M, Campbell BK, Scaramuzzi RJ. The effects of short-term nutritional supplementation with lupins (Lupinus luteus) on the number of ovarian follicles and the concentrations of follicular hormones and glucose in ewes during the luteal phase of the oestrous cycle. Theriogenology. 2007;68:1037-46.

14. Viñoles C, Forsberg M, Martin GB, Cajarville C, Repetto J, Meikle A. Short-term nutritional supplementation of ewes in low body condition affects follicle development due to an increase in glucose and metabolic hormones. Reproduction. 2005;129:299-309.

15. Kendall NR, Gutiérrez CG, Scaramuzzi RJ, Baird DT, Webb R, Campbell BK Direct in vivo effects of leptin on ovarian steroidogenesis in sheep. Reproduction. 2004;12:757-65.

16. Downing JA, Joss J, Scaramuzzi RJ. Ovulation rate and the concentrations of gonadotrophins and metabolic hormones in ewes infused with glucose during the late luteal phase of the oestrous cycle. J Endocrinol. 1995; 146:403-10.

17. Muñoz-Gutiérrez M, Blache D, Martin GB, Scaramuzzi RJ. Folliculogenesis and ovarian expression of mRNA encoding aromatase in anoestrous sheep after 5 days of glucose or glucosamine infusion or supplementary lupin feeding. Reproduction. 2002;124:721-31.

18. Gallet C, Dupont J, Campbell BK, Monniaux D, Scaramuzzi RJ. The infusion of glucose in ewes during the luteal phase increases the number of follicles but reduces oestradiol production and some correlates of metabolic function in the large follicles. Anim Reprod Sci. 2011;127:154-63.

19. Dupont J, Chabrolle C, Ramé C, Tosca L, Coyral-Castel S. Role of the peroxisome proliferator-activated receptors, adenosine monophosphateactivated kinase, and adiponectin in the ovary. PPAR Res. 2008;2008:176275.

20. Somchit-Assavacheep A, Campbell BK, Khalid M, Kendall NR, Scaramuzzi RJ. The effect of short-term nutritional supplementation of ewes with lupin grain (Lupinus luteus) on folliculogenesis, the concentrations of hormones and glucose in plasma and follicular fluid and the follicular levels of $P_{450}$ aromatase and IRS-1, 2 and 4. Reproduction. 2013;145:319-33.

21. Williams SA, Blache D, Martin GB, Foot RM, Blackberry MA, Scaramuzzi RJ. Effect of nutritional supplementation on quantities of glucose transporters 1 and 4 in sheep granulosa and theca cells. Reproduction. 2001;122:947-56.

22. Nishimoto $H$, Matsutani R, Yamamoto S, Takahashi T, Hayashi KG, Miyamoto A, et al. Gene expression of glucose transporter (GLUT) 1, 3 and 4 in bovine follicle and corpus luteum. J Endocrinol. 2006;188:111-9.

23. Zhang C, Niu W, Wang Z, Wang X, Xia G. The effect of gonadotropin on glucose transport and apoptosis in rat ovary. PLoS One. 2012;7(8):e42406. doi:10.1371 journal.pone.0042406.

24. Poretsky L, Cataldo NA, Rosenwaks Z, Giudice LC. The insulin-related ovarian regulatory system in health and disease. Endocr Rev. 1999;20:535-82.
25. Webb R, Campbell BK, Garverick HA, Gong JG, Gutierrez CG, Armstrong DG. Molecular mechanisms regulating follicular recruitment and selection. J Reprod Fert. 1999;54(Suppl):33-48.

26. Armstrong DG, Gong JG, Webb R. Interactions between nutrition and ovarian activity in cattle: physiological, cellular and molecular mechanisms. Reproduction. 2003;61(Suppl):403-14.

27. Zouaïdi N, Dupont J, Khaldi G, Scaramuzzi RJ. The effect of short-term treatment of ewes with either intravenous glucose or a supplement of soya and maize during the luteal phase on the number of follicles and the AMPK signalling pathway in granulosa and theca cells. In: Chilliard Y, Glasser F, Faulconnier Y, Bocquier F, Veissier I, Doreau M, editors. Ruminant Physiology: Proceedings of the XIth International Symposium on Ruminant Physiology. Wageningen, The Netherlands: Wageningen Academic Publishers; 2009. p. 786-7.

28. Agabriel J. INRA Alimentation des Bovines, Ovins et Caprins: Besoins des Animaux - Valeurs des Aliments. Tables INRA 2007, mise à jour 2010. Versailles, France: éditions Quae; 2013.

29. Campbell BK. Factors affecting ovulation rate in sheep and cattle. PhD thesis. University of Sydney, Department of Animal Science; 1988.

30. Carson RS, Findlay JK, Clarke IJ, Burger HG. Oestradiol, testosterone, and androstenedione in ovine follicular fluid during growth and atresia of ovarian follicles. Biol Reprod. 1981;24:105-13.

31. Menassol J-B, Collet A, Chesneau D, Malpaux B, Scaramuzzi RJ. The interaction between photoperiod and nutrition and its effects on seasonal rhythms of reproduction in the ewe. Biol Reprod. 2012;86:1-12.

32. Ben Said S, Lomet D, Chesneau D, Lardic L, Canepa S, Guillaume D, et al. Differential estradiol requirement for the induction of estrus behaviour and the luteinizing hormone surge in two breeds of sheep. Biol Reprod. 2007;76:673-80.

33. Faure MO, Nicol L, Fabre S, Fontaine J, Mohoric N, McNeilly AS, et al. BMP-4 inhibits follicle-stimulating hormone secretion in ewe pituitary. J Endocrinol. 2005;186:109-21.

34. Canépa S, Laine A-L, Bluteau A, Fagu C, Flon C, Monniaux D. Validation d'une méthode immunoenzymatique pour le dosage de la progestérone dans le plasma des ovins et des bovins. Cahier des Techniques de I'INRA. 2008;64:19-30

35. Kosior-Korzecka U, Bobowiec R. Changes in the level of endogenous leptin, FSH, 17beta-oestradiol and metabolites during lupin-induced increase in ovulation rate in ewes. J Vet Med A Physiol Pathol Clin Med. 2003;50:343-9.

36. Viñoles C, Paganoni B, Glover KM, Milton JT, Blache D, Blackberry MA, et al. The use of a 'first-wave' model to study the effect of nutrition on ovarian follicular dynamics and ovulation rate in the sheep. Reproduction. 2010;140:865-74.

37. Letelier C, Gonzalez-Bulnes A, Herve M, Correa J, Pulido R. Enhancement of ovulatory follicle development in maiden sheep by short-term supplementation with steam-flaked corn. Reprod Dom Anim. 2008:43:222-7.

38. Letelier C, Mallo F, Encinas T, Ros JM, Gonzalez-Bulnes A. Glucogenic supply increases ovulation rate by modifying follicle recruitment and subsequent development of preovulatory follicles without effects on ghrelin secretion. Reproduction. 2008;136:65-72.

39. Berlinguer F, Gonzalez-Bulnes A, Contreras-Solis I, Spezzigu A, Torres-Rovira $L$, Succu S, et al. Glucogenic supply increases oocyte developmental competence in sheep. Reprod Fert Dev. 2012;24:1055-62.

40. Scaramuzzi RJ, Land RB. Oestradiol levels in sheep plasma during the oestrous cycle. J Reprod Fert. 1978;53:167-71.

41. Ying S, Wang Z, Wang C, Nie H, He D, Jia R, et al. Effect of different levels of short-term feed intake on folliculogenesis and follicular fluid and plasma concentrations of lactate dehydrogenase, glucose, and hormones in $\mathrm{Hu}$ sheep during the luteal phase. Reproduction. 2011;142:699-710.

42. Ying SJ, Xiao SH, Wang CL, Zhong BS, Zhang GM, Wang ZY, et al. Effect of nutrition on plasma lipid profile and mRNA levels of ovarian genes involved in steroid hormone synthesis in Hu sheep during luteal phase. J Anim Sci. 2013;91:5229-39.

43. Downing JA, Joss J, Scaramuzzi RJ. The effect of a direct arterial infusion of insulin and glucose on the ovarian secretion rates of androstenedione and oestradiol in ewes with an autotransplanted ovary. J Endocrinol. 1999;163:531-41.

44. Scaramuzzi RJ, Murray JF, Downing JA, Campbell BK. The effects exogenous growth hormone on follicular steroid secretion and ovulation rate in sheep. Dom Anim Endocrinol. 1999;17:269-77.

45. Scaramuzzi RJ, Baird DT, Campbell BK, Driancourt MA, Dupont J, Fortune JE, et al. Regulation of folliculogenesis and the determination of ovulation rate in ruminants. Reproduction Fertility and Dev. 2011;23:444-67. 
46. Monget P, Besnard N, Huet C, Pisselet C, Monniaux D. Insulin-like growth factor-binding proteins and ovarian folliculogenesis. Horm Res. 1996;45:211-7. 47. Monget $P$, Fabre $S$, Mulsant $P$, Lecerf F, Elsen JM, Mazerbourg S, et al. Regulation of ovarian folliculogenesis by IGF and BMP system in domestic animals. Dom Anim Endocrinol. 2002;23:139-354.

48. Campbell BK, Baird DT. Inhibin A is a follicle stimulating hormone-responsive marker of granulosa cell differentiation, which has both autocrine and paracrine actions. J Endocrinol. 2001;169:333-45.

49. Evans AC, Martin F. Kinase pathways in dominant and subordinate ovarian follicles during the first wave of follicular development in sheep. Anim Reprod Sci. 2000;64:221-31.

50. Ryan KE, Casey SM, Canty MJ, Crowe MA, Martin F, Evans AC. Akt and Erk signal transduction pathways are early markers of differentiation in dominant and subordinate ovarian follicles in cattle. Reproduction. 2007:133:617-26.

51. Ryan KE, Glister C, Lonergan P, Martin F, Knight PG, Evans AC. Functional significance of the signal transduction pathways Akt and Erk in ovarian follicles: in vitro and in vivo studies in cattle and sheep. J Ovar Res. 2008;1:2. doi:10.1186/1757-2215-1-2.

52. Tosca L, Chabrolle C, Dupont J. AMPK: a link between metabolism and reproduction? Med Sci (Paris). 2008;24:297-300.

53. Taniguchi CM, Emanuelli B, Kahn CR. Critical nodes in signalling pathways: insights into insulin action. Nature Mol Cell Biol. 2006;7:85-96.

doi:10.1186/1477-7827-13-6

Cite this article as: Scaramuzzi et al:: The effects of intravenous, glucose versus saline on ovarian follicles and their levels of some mediators of insulin signalling. Reproductive Biology and Endocrinology 2015 13:6.

\section{Submit your next manuscript to BioMed Central and take full advantage of:}

- Convenient online submission

- Thorough peer review

- No space constraints or color figure charges

- Immediate publication on acceptance

- Inclusion in PubMed, CAS, Scopus and Google Scholar

- Research which is freely available for redistribution 